
\title{
$\begin{array}{ll}\text { Research Square } & \begin{array}{l}\text { Preprints are preliminary reports that have not undergone peer review. } \\ \text { They should not be considered conclusive, used to inform clinical practice, } \\ \text { or referenced by the media as validated information. }\end{array}\end{array}$
}

\section{Helicobacter pylori infection and increased diabetes prevalence were the risks of colorectal adenoma: a systematic review and meta-analysis}

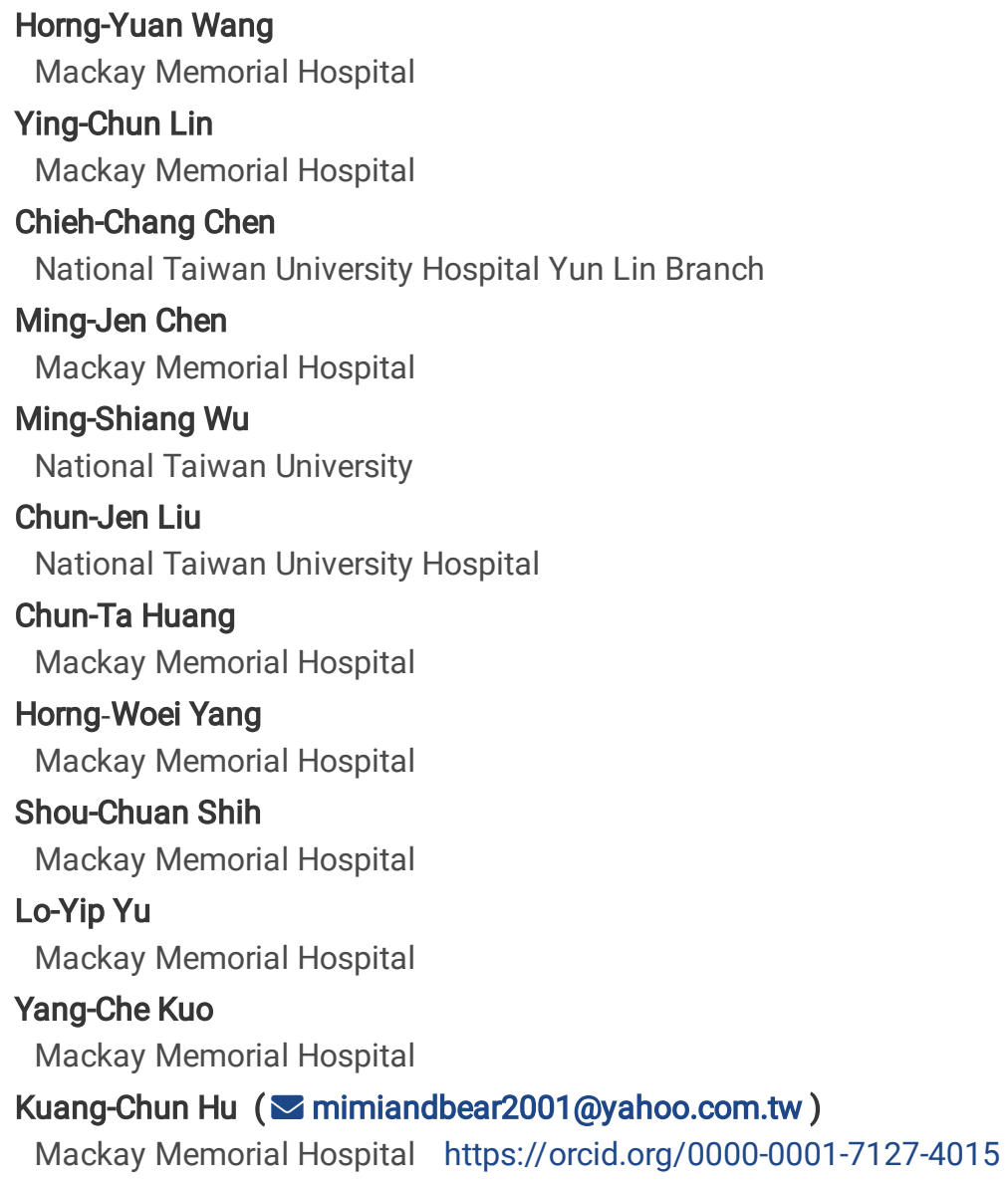

Research article

Keywords: Helicobacter pylori, Diabetes prevalence, colorectal adenoma

Posted Date: July 6th, 2019

DOI: https://doi.org/10.21203/rs.2.11064/v1

License: (c) (1) This work is licensed under a Creative Commons Attribution 4.0 International License. Read Full License 


\section{Abstract}

Background Helicobacter pylori (H. Pylori) infection and hyperglycemia may be associated with an increased risk of colorectal neoplasm. However these two factors affect colorectal neoplasm remain controversial. We aimed to carry out a meta-analysis to evaluate the study population diabetes prevalence rate and $\mathrm{H}$. pylori infection rate with colorectal adenoma risk. Methods We conducted a systemic research through English databases for medical reports. We also recorded the diabetes prevalence and $\mathrm{H}$. pylori infection prevalence in each study. We classified these studies into 4 subgroups as their background population diabetes prevalence $<6 \%$ (Group 1); between 6 to $8 \%$ (Group 2); between 8 to 10\%(Group 3) and more than 10\%(Group 4). The random effects model had used to calculate pooled prevalence estimates with $95 \%$ confidence interval [Cl]. Results Twenty seven studies were finally eligible for metaanalysis. The random-effects model of meta-analysis was chosen, showing pooled odds ratio (OR) equal to 1.51 (95\% $\mathrm{Cl} 1.39-1.63)$. The subgroup meta-analyses showed in Group 1 the H. pylori infection associated colorectal adenoma risk OR was $1.24(95 \% \mathrm{Cl} 0.86-$ 1.78). As diabetes rate exceed $6 \%$, the $\mathrm{H}$. pylori infection became more significant increased risk of colorectal adenoma (Group 2: OR 2.16 (95\% Cl 1.61-2.91); Group 3: OR 1.40 (95\% Cl 1.24-1.57); Group 4: OR 1.52 (95\% Cl 1.46-1.57)). Conclusions The results of this meta-analysis showed DM prevalence would affect the risk factor of colorectal adenoma with H. pylori infection.

\section{Core Tip:}

This is a systematic review with meta-analysis of published studies reporting the correlation of $H$. pylori infection and colorectal adenoma. Through the meta-regression to DM prevalence, we believed that DM would affect the risk of colorectal adenoma with $H$. pylori infection.

\section{Background}

Helicobacter pylori (H. pylori) is a Gram-negative bacterium that has infected almost 50\% of the world's population[1]. Since $1994, H$. pylori has been recognized as a human carcinogen by the International Agency for Research on Cancer due to its strong correlation with gastric cancer [2]. Except for intragastric malignancy disease, many scientists have noted that this bacterium is also related to colon neoplasms and colorectal carcinoma (CRC) formation and have shown that infection with H. pylori confers a 1.3-1.97-fold increased risk of colon adenoma or adenoma with high-grade dysplasia in the past two decades [3-5]. However, some Asian studies did not show consistent results. Early studies showed that $H$. pylori infection may have a trend of increased colon adenoma but no significant difference [6,7]. Recent studies have demonstrated a positive association between $H$. pylori infection and colon adenoma formation [8.9]. In these studies, Sonnenberg and Genta [3] established the largest study, which included 156,000 patients, and showed that $H$. pylori gastritis was positively associated with colon adenomas (odds ratio $(\mathrm{OR})=1.52$ ). Even with this impressive study result, Plummer also commented and queried several key points [10]. The most important question that needs to be answered is how to explain why some areas had a high prevalence of $H$. pylori infection but a low CRC risk. Several meta-analysis studies have shown that $H$. pylori infection increases the risk of colorectal neoplasm formation[11-13]. However, these studies did not address Plummer's query.

Diabetes mellitus type 2 (DM) is one of the most common metabolic disorders in the world, and the prevalence of DM has been increasing quickly in recent decades [14]. The prevalence of DM also has significant regional variability. According to the latest report, the highest prevalence of DM was found in North America and the Caribbean region, and the prevalence in this region was approximately $11.0 \%$. The Western Pacific region (including Australia, China, Indonesia, Japan, Taiwan, Korea and Vietnam) has a DM prevalence of approximately 8.1\% [15]. However, as socioeconomic growth and industrialization are rapidly occurring in this area, the increasing prevalence of diabetes was also noted in these countries[16]. DM is also considered a risk factor for colon adenoma and carcinoma. Several studies have shown that subjects with DM had an OR of 1.45 for colon adenoma and a relative risk of 1.38 for colorectal adenocarcinoma[17, 18]. Our previous study demonstrated that combined hyperglycemia and $H$. pylori infection was involved in colon adenoma formation and had a synergistic effect[19]. The risk of colorectal adenoma might decrease after $H$. pylori is successfully eradicated[20]. This means that hyperglycemia and $H$. pylori infection might interact and affect colorectal adenoma formation.

Therefore, we carried out a systematic review and meta-analysis of published studies to evaluate the association between $H$. pylori infection and colorectal adenoma formation. Furthermore, we surveyed the DM prevalence in each published study as a subgroup analysis and tried to determine the relationship between $H$. pylori infection and DM prevalence in the risk of colon adenoma formation. We tried to use different DM prevalence rates to classify subgroups of these studies to answer Plummer's question and discuss the relationship between the DM prevalence rate and $H$. pylori infection involvement in colorectal adenoma formation. 


\section{Methods}

Data sources and searches

PRISMA statement guidelines were followed for conducting and reporting meta-analysis data. The PICOS scheme was followed for reporting inclusion criteria. A systematic search was conducted using PubMed/MEDLINE, EMBASE, and the Cochrane Library for medical reports published until the end of October 2017 without language or date restrictions. The following search terms were used: "Helicobacter pylor" AND ("colorectal" OR "colonic" OR "colon" OR "large intestine") AND ("neoplasms" OR "polyp" OR "adenoma" OR "cancer"). Abstracts of articles from the literature search were individually evaluated independently for possible inclusion by the three authors (Chen MJ, Wu MS and Yang HW). For all databases, the last search was run on 22 October 2017.

Study selection

The eligible studies enrolled in the meta-analysis satisfied the following criteria: (i) English-language abstract; (ii) full manuscript publication; (iii) study design: clinical trials including cohort studies, cross-sectional studies and case-control studies; (iv) reported OR estimates with corresponding $95 \%$ confidence intervals (Cls) for the relationship between $H$. pylori and colorectal adenoma or provided sufficient raw data to calculate crude ORs and $95 \% \mathrm{Cls}$; and (v) results: the prevalence of patients with colorectal adenoma due to $H$. pylori infection or the risk of colorectal adenoma in H. pylori infection. Studies were excluded if they (i) reported duplicate results that were published in other articles, (ii) investigated only the gastrin level or the recurrence of colorectal neoplasia, or (iii) included a pediatric population.

Data extraction

Three reviewers (Chen CC, Liu CJ, Shih SC) independently extracted data by using a predefined form, and disagreements were resolved by discussion and consensus. Information was collected in each selected study as possible, concerning first author, publication year, research type, publication type, the number of subjects, the country of origin, the prevalence of DM rate of origin, the matching variables, the location of neoplasia, the H. pylori detection method, the sample characteristics (age and sex), the reported OR for colorectal adenoma with $95 \%$ Cls and the covariates adjusted for in the analysis.

Statistical analysis

Three reviewers (Lin YC, Yu LY, Kuo YC) independently assessed the quality of all eligible studies using the ROBINS I scale. The ORs were collected for analysis. Heterogeneity between studies was assessed using both the $\chi 2$ test with a $p$-value $<0.10$ and inconsistency index (I2) with a cut-off of $50 \%$. Pooled effects with $95 \%$ Cls were derived using a fixed effect model unless significant heterogeneity was present, in which case a random effects model was applied. When a study provided different OR estimates based on hospital-based controls and population-based controls, the latter estimates were selected for the combined analysis. We also calculated and presented a summary of the adjusted ORs for the studies that provided adjusted results. Publication bias was evaluated with funnel plot and Egger's test.

We examined the roles of several potential sources of heterogeneity using restricted maximum likelihood-based random-effects metaregression analysis and subgroup analyses according to geographic location, prevalence of diabetes (DM) rate, prevalence of $H$. pylori infection rate, study design, sample size for the cases, subsite of the neoplasia, H. pylori detection method and sex. The estimated DM prevalence rate of each study was referenced from the International Diabetes Federation (IDF) Atlas and local country government data or study results (by Wang HY, Huang CT). We used the mean year of study duration as the DM prevalence rate. According to the diabetes prevalence rate of the study population, we classified the studies to 4 groups: group 1: DM prevalence < 6\%; group 2: DM prevalence from $6 \sim 8 \%$, group 3: DM prevalence from $8 \sim 10 \%$ and group 4: DM prevalence $>10 \%$. Statistical analyses were performed by STATA version 11.0 (STATA Corporation, College Station, TX, USA) and RevMan version 5.3 (The Cochrane Collaboration, Oxford, UK).

\section{Results}

After initial screening, the full text of 281 potentially eligible articles was retrieved for detailed assessment, and 27 studies were eligible for analysis $[3,6,8,9,19,21-42]$. All of the eligible studies presented $O R$ for colorectal adenoma related to $H$. pylori infection. $[3,6,8,9,19,21-$ 42] Nineteen of them are cross-sectional studies $[3,6,8,19,21-24,25-28,30,31,35,37-40]$, and the remaining eight are case-control studies [9, 29, 32-34, 36, 41, 42]. Serology was utilized as the detection method for $H$. pylori in 14 studies [8, 9, 21, 23, 25-27, 31-35, 38, 39], pathology in 4 [3, 22, 40,42], UBT in 4 [6, 37], CLO in 6 [19, 24, 30,36], and combining UBT and CLO in 2 [28, 29]. Gender and age are 
reported in 22 [3,6,8,9,19, 21-30,34-40] and 27 [3,6,8,9,19, 21-35,37-39,41,42] studies respectively. Most studies were carried out in Asia (7 in Korea, 3 in Taiwan, 3 in Japan, 1 in Thailand and 1 in China) and the remaining in Americas (5 in USA and 1 in Brazil) and in Europe (2 in Germany, 1 in Turkey, 1 in Greece and 1 in Israel). All included studies had assessed the quality of all eligible studies using the ROBINS I scale and no serious risk of bias after survey (in Appendix).

A flow chart describing the process of study selection is shown in Figure 1. For the meta-analysis, data were extracted from twenty-seven studies with a total of 68,410 patients, and the pooled OR for colorectal adenoma related to $H$. pylori infection was $1.51(95 \% \mathrm{Cl} 1.39-$ 1.63), although there was significant heterogeneity $(p<0.001)$ (Table 1 and Figure 2$)$. Because of geographic and time differences in DM prevalence rate [43-52], subgroup analysis for the studies was performed by classifying them into 4 groups: group 1: DM prevalence $<6 \%$; group 2: DM prevalence from $6 \sim 8 \%$, group 3: DM prevalence from 8 10\% and group 4: DM prevalence $>10 \%$ (Table 1 and Figure 2).

In the subgroup analysis, the background population DM prevalence $<6 \%$ studies had three studies with a total of 886 patients. Metaanalysis of these studies revealed that the $\mathrm{H}$. pylori-infected patients have an increased risk of having colorectal adenoma with a pooled OR of $1.24(95 \% \mathrm{Cl} 0.86-1.78)$ but no significant difference. There was no significant heterogeneity in group 1 studies $(p=0.279)$. Since the study background population DM prevalence increased more than $6 \%$, the $\mathrm{H}$. pylori-infected patients have significant increased risk of having colorectal adenoma. This upturn was more significant when the background population DM prevalence was approximately $6 \%$ to $8 \%$. After meta-analysis of these studies, the $H$. pylori-infected people had a higher risk of colorectal adenoma than noninfected people. The pooled OR was 2.16 ( $95 \% \mathrm{Cl} 1.61-2.91)$, and a total of 11655 patients were included. In these studies, Lin's study noted the DM prevalence in his study participants, and males had an 8.1\% prevalence of DM, and females had a $6.1 \%$ prevalence of DM. Due to Lin's study population, $6.94 \%$ of patients had DM and were thus classified into group 2 for subgroup analysis. There was significant heterogeneity in the group 2 studies $(p<0.01)$

In groups 3 and 4, similar results were observed. Compared to that of group 2 studies, the pooled OR of groups 3 and 4 was mildly decreased but still had a significantly elevated risk of colorectal adenoma in $H$. pylori-infected patients. For the $H$. pylori-infected patients, the risk of colorectal adenoma in group 3 was 1.40 (95\% $\mathrm{Cl} 1.24-1.57)$, and the group 4 OR was 1.52 (95\% $\mathrm{Cl} 1.46-1.57)$. The group 3 studies included 28,431 patients, and the heterogeneity across studies was marginal $(R=58.6 \%, p=0.013)$. There were 27,438 participants included in group 4 studies, and there was no significant heterogeneity $(R=0.0 \%, p=0.704)$. We also checked other variables, including gender, detection methods of $H$. pylori infection and study designs, and there was no evidence of statistical relevance to $\mathrm{OR}$ for adenoma with $H$. pylori infection.

Test of Heterogeneity and Publication Bias

Heterogeneity was assessed by chi-square and I-square for the included studies. The value of $\chi 2$ was $<0.01$, and the $I^{2}$ was $61.9 \%$. Due to the heterogeneity noted in our analysis, a random effects model was used. The shape of the funnel plots for studies on the association between $\mathrm{H}$. pylori infection and the risk of colorectal adenoma appeared asymmetrical (Figure 3A), which indicated that studies with positive correlation are reported more often. The $p$-value for Egger's linear regression method $(p<0.01)$ suggested that there was statistical evidence of publication bias. (Figure 3 B)

\section{Discussion}

Since the discovery of $H$. pylori as a cause of peptic ulcer disease in 1983, this bacterial infection continues to be a major public health issue worldwide. The prevalence of $H$. pylori infection varies by geographic area, age, ethnicity and socioeconomic status; in fact, the prevalence is higher in developing countries and in those in poor socioeconomic conditions [53]. Traditionally, Western and Eastern countries have different $H$. pylori infection rates in their general populations. The prevalence is highest in Africa (79.1\%), Latin America and Asia (54.7\%). On the other hand, the H. pylori infection rate is lowest in Northern America (37.1\%) and Oceania $(24.4 \%)[54,55]$.

H. pylori infection is the main cause of chronic gastritis and peptic ulcer disease and is the main carcinogen for gastric malignancy disease[56]. In the extragastric system, H. pylori infection has also been reported to be related to inflammatory bowel disease, colorectal neoplasms, and cardiovascular disease; to contribute to insulin resistance, associated metabolic syndrome, diabetes, autoimmune disease, and kidney disease; and to be associated with neurodegenerative disease, respiratory disease and hematologic disease [57,58]. In these studies, most scientists addressed the topic of $H$. pylori infection related to colorectal neoplasm formation[3,6,8,9,19, 21-42]. 
Now that it is known that $H$. pylori is an infectious disease, it can be cured with a course of antibiotics. In recent studies, $H$. pylori infection rate decreased due to public health improvement in developed countries and some developing countries. In many countries, the incidence of $H$. pylori infection has been decreasing in association with improved standards of living and levels of hygiene. However, as the prevalence rate of $H$. pylori infection remains high in most developing countries and is generally related to socioeconomic status, it remains one of the most important diseases in these areas[55]. Hong et al. published a meta-analysis of $H$. pylori infection and increased the risk of colorectal adenoma formation. In this study, he focused on Eastern or Western studies for subgroup analysis and found that the ORs of these two groups were similar[25]. This means that even the $H$. pylori infection prevalence was different in Eastern and Western countries, and this bacterial infection still increased colorectal adenoma formation. It also hints to a link between $H$. pylori infection and colorectal adenoma formation, which may be due to the third factor in this connection.

Unlike $H$. pylori infection disease, the prevalence of DM in the global world has persisted. The age-standardized DM prevalence increased from $4.3 \%$ in 1980 to $9.0 \%$ in 2014 in men and from 5.0\% to $7.9 \%$ in women[59]. The rise in prevalence might be due to population growth and aging, as the number of adults with diabetes has increased nearly 4-fold over the past 35 years. The prevalence and number of adults with diabetes both increased and doubled in men and increased by $60 \%$ in women worldwide, shifting from an excess prevalence in women in 1980 to a higher male prevalence in 2014[60]. Persistent high blood sugar concentrations lead to damage to the blood vessels and peripheral nerves. This situation might result in an increased risk of cardiovascular diseases, such as heart attack and stroke, kidney disease, diabetic retinopathy and foot amputations [61]. DM is also considered an increased risk factor for colon adenoma and carcinoma[62]. These DM-related complications lead to higher costs for the health care system [63] as well as lower quality of life and reduced life expectancy [64].

A past study showed that DM prevalence was low in much of Asia and sub-Saharan Africa in the 1980s and 1990s[57,65]. However, several recent reports have demonstrated that the DM prevalence has increased in China, India, Turkey and Saudi Arabia[66-69]. Some high-income English-speaking countries, such as the USA and the UK, $[70,71]$ also reported increased DM prevalence. On the other hand, DM prevalence did not increase in Western Europe, and some reports from Sweden, Germany and Switzerland showed similar results[72,73]. In accordance with a previous statement and based on geographical distribution, the prevalence of $H$. pylori infection and DM seems to be inversely related. In our study, when the background population DM prevalence was below $6 \%, H$. pylori infection did not significantly increase the risk of colorectal adenoma formation (Group 1). This association became significant when the study population DM prevalence was over 6\% (Group 2-4). The odds ratio of $\mathrm{H}$. pylori infection-related colorectal formation was 2.16 (95\% $\mathrm{Cl}$ 1.61-2.91); it was the highest when the population DM prevalence was from 6 8\% (Group 2). However, when the DM prevalence rate was elevated to $8 \sim 10 \%$ or more than $10 \%$ (Group 3, Group 4), the OR was mildly decreased to 1.40 (95\% $\mathrm{Cl} 1.24-1.57)$ and 1.52 (95\% Cl 1.46-1.57). H. pylori infection still significantly increased colorectal adenoma but was not distinct from Group 2 (DM prevalence between 6 and 8\%). However, when DM prevalence increased, $H$. pylori infection might increase the risk of colorectal adenoma formation.

The cause of this condition may be related to the study period and location. Most studies in group 2 were carried out from 1996 to 2000 , and group 3 studies were carried out from 2000 to 2010. The study's location may also affect this result. Most of the Group 3 studies were from Korea, and Group 4 studies were from the USA. The Group 2 studies were more heterogeneous in location, including Japan, Taiwan, Turkey, Israel and Germany. The $H$. pylori infection rate of the study population was also collected and is shown in Table 1. There was no significant difference in the ORs of $H$. pylori infection-associated colorectal adenoma between the lower infection rate area (USA or Germany, 35.3\% to 35.6\%) and the middle infection rate area (Japan, Korea, China, Taiwan; approximately 51.7\% to 55.8\%).

Further evaluation for the other reason that Group 2 studies revealed higher ORs in $\mathrm{H}$. pylori infection- associated colorectal adenoma is necessary. In addition, our study might partially answer Plummer's query "How to explain that some areas had a high prevalence of $H$. pylori infection but low CRC risk?" [10] According to our study, we could see that Brazil et al. had a higher $H$. pylori infection prevalence (71.2\%) but a lower DM prevalence rate (5.8\%). (Table 1) Buso's study demonstrated that the $H$. pylori infection proportion did not significantly increase colorectal adenoma risk (OR: 1.98, 95\% Cl 0.82-3.15). [34] However, when the DM prevalence was higher (> 10\%), even when the $H$. pylori infection rate was lower (35.6\%), the OR of colorectal adenoma with $H$. pylori infection was significantly increased (Group 4: OR: 1.52, 95\% Cl 1.46-1.57). This means that the DM prevalence rate might be the key factor of increased colorectal adenoma risk with $H$. pylori infection.

Our previous study demonstrated the interaction of hyperglycemia and $H$. pylori infection in colon adenoma formation. We found that the OR for adenoma was $1.437(95 \% \mathrm{Cl} 1.197-1.726)$ if $\mathrm{H}$. pylori was present or $1.629(95 \% \mathrm{Cl} 1.239-2.14)$ if $\mathrm{HbA}_{1 \mathrm{c}} \geq 6.5$. When combining these two factors, the OR was elevated to 4.712 (95\% Cl 3.189- 6.963), suggesting that these two factors may have a synergistic effect in colorectal adenoma[19]. The likely reason for the synergistic effect may involve several processes. First, 
hyperglycemia status affected gastrointestinal morphology and function and resulted in gut barrier loss and changes in intestinal mucosa permeability. Second, high-fat and high-caloric diets also increase gut permeability, and this situation was more significant in DM patients[74]. Third, some intestinal microorganism-related products, such as lipopolysaccharides, would more efficiently pass through the gut barrier and stimulate the Toll-like receptors in the mucosa. This would trigger a serious inflammatory process, and finally, IL-17 and IL- 6 will increase. IL-17 activates the signal transducer and activator of the transcription 3 pathway, promoting cell proliferation and survival and finally inducing tumorigenesis [75].

These animal models and individualized study results support this study finding that states that an elevated DM prevalence rate enhances the risk of colorectal adenoma in H. pylori-infected populations. Our study still had several limitations. First, in our subgroup analysis, we found that the Group 2 studies had more heterogeneity. The reason for this condition may be related to population studies with differences in study location, population, aging, and gender. Despite this heterogeneity, H. pylori infection also increased the risk of colorectal adenoma. Second, the asymmetry of the results of Egger's test and funnel plots suggested the possibility of publication bias. However, because most of our included studies [3,6,8,9,19,21-42] had statistically significant results, Egger's test and funnel plots would show asymmetry. Third, the population DM prevalence rate might not completely represent our included studies participant's diabetes condition. Only Lin et al. [24] and Hu et al. [19] included the DM prevalence rate in their studies. To the best of our knowledge, we tried to estimate the diabetes rate of each study as accurately as possible.

\section{Conclusion}

In conclusion, our study demonstrated that population DM prevalence affects the risk of colorectal adenoma with $H$. pylori infection. Since diabetes prevalence was over $6 \%$ in the background study population, $H$. pylori infection became a more significant factor in inducing colorectal adenoma formation. Given the increasing prevalence of diabetes in the world, $H$. pylori eradication and hyperglycemia control might have an impact on the prevention of colorectal neoplasm formation.

\section{List Of Abbreviations}

H. pylori : Helicobacter pylori

$\mathrm{HbA}_{1 \mathrm{c}}$ : glycosylated hemoglobin

DM: diabetes mellitus

CRC: colorectal carcinoma

Cl: confidence intervals

OR: odds ratio

\section{Declarations}

Ethics approval and consent to participate: Not applicable

Consent for publication: Not applicable

Availability of data and material: The datasets used and/or analysed during the current study are available from the corresponding author on reasonable request.

Competing interests: The authors declare that they have no competing interests

Funding: MMH-108-31

Author contributions: Chen MJ, Wu MS and Yang HW acquisition of data; Chen CC, Liu CJ, Shih SC analysis and interpretation of data; Lin YC, Yu LY, Kuo YC interpretation and analysis of data, revising the article; Huang CT and Wang HY for prevalence of diabetes survey and interpretation of data, revising the article; Hu KC conception and design of the study, critical revision, final approval.

Acknowledgements: Departments of Medical Research, MacKay Memorial Hospital, Taipei

Page 6/14 


\section{References}

1. Muhammad JS, Zaidi SF, Sugiyama T. Epidemiological ins and outs of helicobacter pylori: a review. J Pak Med Assoc 2012; 62 : 955-959 [PMID: 23139983]

2. IARC Monogr Eval Carcinog Risks. Hum 1994; 61: 177-240 [PMID: 7715070]

3. Sonnenberg A, Genta, RM. Helicobacter pylori is a risk factor for colonic neoplasms. AM J Gasteroenterol 2013; 108: 208-215 [PMID: 23208272 DOI: 10.1038/ajg.2010.407]:

4. Rokkas T, Sechopoulos P, Pistiolas D, Kothonas F, Margantinis G, Kouklulis G. The relationship of Helicobacter pylori infection and colon neoplasia, on the basis of meta-analysis. Eur J Gastroenterol Hepatol 2013; 25: 1286-1294 [PMID: 23820245]

5. Kapetanakis N, Kountouras J, Zayos C, Michael S, Tsarouchas G, Gavalas E, Anastasiadou K, Tsiaousi E, Venizelos I, Nikolaidou C, Vardaka E, Kouklakis G, Moschos I. Helicobacter pylori infection and colorectal cancer risk: evidence from a large population-based case-control study in Germany. Am J Epidemiol 2012; 176: 566-567 [PMID: 22908208 DOI: 10.1093/aje/kws302]

6. Liou JM, Lin JW, Huang SP, Lin JT, Wu MS. Helicobacter pylorinfection is not associated with increased risk of colorectal polyps in Taiwanese. Int J Cancer 2006; 119: 1999-2000 [PMID: 16708392 DOI: 10.1002/ijc.22050]

7. Machida-Montani A, Sasazuki S, Inoue M, Natsukawa S, Shaura K, Koizumi Y, Kasuda Y, Hanaoka T, Tsugane S. Atrophic gastritis, Helicobacter pylori, and colorectal cancer risk: A case-control study. Helicobacter 2007;12: 328-32 [PMID: 17669106]

8. Nam KW, Baeg MK, Kwon JH, Cho SH, Na SJ, Choi MG. Helicobacter pyloriseropositivity is positively associated with colorectal neoplasms. Korean J Gastroenterol 2013; 61:259-64 [PMID: 23756667]

9. Inoue I, Mukoubayashi C, Yoshimura N, Niwa T, Deguchi H, Watanabe M, Enomoto S, Maekita T, Ueda K, Iquchi M, Yanaoka K, Tamai H, Arjj K, Oka M, Fujishiro M, Takeshita T, Iwane M, Mohara O, Ichinose M. Elevated risk of colorectal adenoma with Helicobacter pylori-related chronic gastritis: A population-based case-control study. Int J Cancer 2011; 129: 2704-2711 [PMID: 21225622 DOI: 10.1002/ijc.25931]

10. Plummer M. Helicobacter pylori and Colonic Neoplasms. AM J Gasteroenterol 2013; 108: 216-217 [PMID:23381070 DOI: 10.1038/ajg.2012.409]

11. Chen YS, Xu SX, Ding YB, Huang XE, Deng B. Helicobacter pylori infection and the risk of colorectal adenoma and adenocarcinoma: an updated meta-analysis of different testing methods. Asian Pac J Cancer Prev 2013; 14: 7613-7619 [PMID: 24460342]

12. Wu Q, Yang ZP, Xu P, Gao LC, Fan DM. Association between Helicobacter pylori infection and the risk of colorectal neoplasia: a systematic review and meta- Colorectal Dis 2013; 15: e352-e364 [PMID: 23672575 DOI: 10.1111/codi.12284 ]

13. Rokkas T, Sechopoulos P, Pistiolas D, Kothonas F, Margantinis G, Koukoulis G. The relationship of Helicobacter pylori infection and colon neoplasia, on the basis of meta-analysis. Eur J Gastroenterol Hepatol 2013; 25: 1286-1294 [PMID: 23820245]

14. Guariguata L, Whiting DR, Hambleton I, Beagley J, Linnenkamp U, Shaw JE. Global estimates of diabetes prevalence for 2013 and projections for 2035. Diabetes Res Clin Pract 2014; 103: 137-149 [PMID: 24630390]

15. American Diabetes Association. Diagnosis and classification of diabetes mellitus. Diabetes Care 2010; 33: S62-9

16. Ramachandran A, Snehalatha C, Shetty AS, Nanditha A. Trends in prevalence of diabetes in Asian countries. World J Diabetes 2012; 3:110-117 [PMID: 22737281 DOI: 10.4239/wjd.v3.i6.110 ]

17. Eddi R, Karki A, Shah A, DeBari VA, DePasquale JR. Association of type 2 diabetes and colon adenomas. J Gastrointest Cancer 2012; 43: 87-92 [PMID: 21894459]

18. Yuhara H, Steinmaus C, Cohen SE, Corley DA, Tei Y, Buffler PA. Is diabetes mellitus an independent risk factor for colon cancer and rectal cancer\&quest. Am J Gastroentero/ 2011; 106:1911-1921 [PMID: 21912438 DOI: 10.1038/ajg.2011.301]

19. Hu KC, Wu MS, Chu CH, Wang HY, Lin SC, Liu SC, Liu CC, Su TH, Chen TH, Chen CL, Liu CJ, Shih SC. Synergistic effect of hyperglycemia and Helicobacter pylori infection status on colorectal adenoma risk. J Clin Endocrinol Metab 2017; 102: $2017-00257$. [PMID: 28475740 DOI: 10.1210/jc.2017-00257]

20. Hu KC, Wu MS, Chu CH, Wang HY, Lin SC, Liu CC, Su TH, Liao WC, Chen CL, Liu CJ, Shih SC. Decreased Colorectal Adenoma Risk after Helicobacter pylori Eradication: A Retrospective Cohort Study. Clin Infect Dis 2018 [PMID: 30566695 DOI: 10.1093/cid/ciy591]

21. Mizuno S, Morita Y, Inui T, Asakawa A, Ueno N, Ando T, Kato H, Uchida M, Yoshikawa T, Inui A. Helicobacter pylori infection is associated with colon adenomatous polyps detected by high-resolution colonoscopy. Int J Cancer 2005; 117: $1058-1059$ [PMID: 15986436 DOI: 10.1002/ijc.21280] 
22. Brim H, Zahaf M, Laiyemo AO, Nouraie M, Pérez-Pérez GI, Smoot DT, Lee E, Ashktorab H. Gastric Helicobacter pylori infection associates with an increased risk of colorectal polyps in African Americans. BMC cancer 2014;14: 296 [PMID: 24774100]

23. Selgrad M, Bornschein J, Kandulski A, Hille C, Weigt J, Roessner A, Wex T, Malfertheiner P. Helicobacter pylori but not gastrin is associated with the development of colonic neoplasms. Int J Cancer 2014; 135: 1127-1131 [PMID: 24496701 DOI: 10.1002/ijc.28758]

24. Lin YL, Chiang JK, Lin SM, Tseng CE. Helicobacter pylori infection concomitant with metabolic syndrome further increase risk of colorectal adenomas. World J Gastroenterol 2010; 16: 3841-3846 [PMID: 20698048]

25. Hong SN, Lee SM, Kim JH, Lee TY, Kim JH, Choe WH, Lee SY, Cheon SY, Sung YK, Park HS, Shim CS. Helicobacter pylori infection increases the risk of colorectal adenomas: cross-sectional study and meta-analysis. Dig Dis Sci 2012; 57: 2184-2194. [PMID: 22669208]

26. Aydin A, Karasu Z, Zeytinoglu A, Kumanlioglu K, Özacar T. Colorectal adenomateous polyps and Helicobacter pyloriAm J Gastroenterol 1999; 94: 1121-1122 [PMID: 10201512]

27. Siddheshwar RK, Muhammad KB, Gray JC, Kelly SB. Seroprevalence of Helicobacter pylori in patients with colorectal polyps and colorectal carcinoma. Am J Gastroenterol 2001; 96: 84-88 [PMID: 11197293]

28. Fujimori S, Kishida T, Kobayashi T, Sekita Y, Seo T, Nagata K, Yamashita K, Ohaki Y, Sakamato C. Helicobacter pylori infection increases the risk of colorectal adenoma and adenocarcinoma, especially in women. J Gastroenterol 2005; 40: 887-893 [PMID:16211345]

29. Bae RC, Jeon S W, Cho HJ, Jung MK, Kweon YO, Kim SK. Gastric dysplasia may be an independent risk factor of an advanced colorectal neoplasm. World J Gastroenterol 2009; 15: 5722-5726 [PMID: 19960571]

30. Abbass K, Gul W, Beck G, Markert R, Akram S. Association of Helicobacter pylori infection with the development of colorectal polyps and colorectal carcinoma. South Med J 2011; 104: 473-476 [PMID: 21886044]

31. Shmuely H, Melzer E, Braverman M, Domniz N, Yahav J. Helicobacter pylori infection is associated with advanced colorectal neoplasia. Scand J Gastroenterol 2014; 49: 35-42 [PMID: 24490722]

32. Breuer-Katschinski B, Nemes K, Marr A, Rump B, Leiendecker B, Breuer N, Goebell, H. Helicobacter pylori and the risk of colonic adenomas. Digestion 1999; 60: 210-215 [PMID: 10343134 DOI: 10.1159/000007661]

33. Georgopoulos SD, Polymeros D, Triantafyllou K, Spiliadi C, Mentis A, Karamanolis DG, Ladas SD. Hypergastrinemia is associated with increased risk of distal colon adenomas. Digestion 2006; 74: $42-46$ [PMID:17068397]

34. Buso AG, Rocha H L O G, Diogo DM, Diogo P M, Diogo-Filho A. Seroprevalence of Helicobacter pylori in patients with colon adenomas in a Brazilian university hospital. Arq Gastroenterol 2009; 46: 97-101 [PMID: 19578608]

35. Kim TJ, Kim ER, Chang DK, Kim YH, Baek SY, Kim K, Hong SN. Helicobacter pylori infection is an independent risk factor of early and advanced colorectal neoplasm. Helicobacter 2017; 22 [ PMID: 28124492 DOI: 10.1111/hel.12377]

36. Nam JH, Hong CW, Kim BC, Shin A, Ryu KH, Park BJ, Kim B, Sohn DK, Han KS, Kim J, Lee CW. Helicobacter pylori infection is an independent risk factor for colonic adenomatous neoplasms. Cancer Causes Control 2017; 28: 107-115 [PMID: 28025763]

37. Yan Ye, Chen YN, Zhao Q, Chen C, Lin CJ, Jin Y, Pan S, Wu JS. Helicobacter pylori infection with intestinal metaplasia: An independent risk factor for colorectal adenomas. World J Gastroenterol 2017; 23: 1443-1449 [PMID: 28293091]

38. Park YM, Kim HS, Park JJ, Baik SJ, Youn YH, Kim JH, Park H. A simple scoring model for advanced colorectal neoplasm in asymptomatic subjects aged 40-49 years. BMC Gastroenterol 2017; 17 [PMID: 28068908 DOI: 10.1186/s12876-016-0562-9]

39. Lee JY, Park HW, Choi JY, Lee JS, Koo JE, Chung EJ, Chang HS, Choe J, Yang DH, Myung SJ, Jung HY, Yang SK, Byeon JS. Helicobacter pylori infection with atrophic gastritis is an independent risk factor for advanced colonic neoplasm. Gut Liver 2016; 10: 902-909 [PMID: 27458180 DOI: 10.5009/gnl15340]

40. Tongtawee T, Kaewpitoon S, Kaewpitoon N, Dechsukhum C, Leeanansaksiri W, Loyd RA. Helicobacter pylori associated gastritis increases risk of colorectal polyps: a hospital based-cross-sectional study in Nakhon Ratchasima Province, Northeastern Thailand. Asian Pac J Cancer Prev 2016; 17: 341-345 [PMID: 26838234]

41. Zuniga R, Bautista J, Sapra K, Westerfield K, Williams S, Sy AM. Combination of Triple Therapy and Chronic PPI Use May Decrease Risk of Colonic Adenomatous Polyps in Helicobacter pylori Gastroenterol Res Pract 2015; 2015: 638547 [PMID: 26064095]

42. Patel S, Lipka S, Shen H, Barnowsky A, Silpe J, Mosdale J, Viswanathan P, Mustacchia P, Krishnamachar B. The association of pylori and colorectal adenoma: does it exist in the US Hispanic population? J Gastrointest Oncol 2014; 5: 463-8 [PMID: 25436126] 
43. Charvat H, Goto A, Goto M, Inoue M, Heianza Y, Arase Y, Tuomilehto J, Tsugane S, Noda M, Inoue M. Impact of population aging on trends in diabetes prevalence: A meta-regression analysis of 160,000 Japanese adults. J diabetes investing 2015; 6: 533-542 [PMID: 26417410 DOI: 10.1111/jdi.12333]

44. Menke A, Casagrande S, Geiss L, Cowie CC. Prevalence of and trends in diabetes among adults in the United States, $1988-2012$. JAMA 2015; 314: 1021-1029 [PMID: 26348752]

45. Whiting DR, Guariguata L, Weil C, Shaw J. IDF diabetes atlas: global estimates of the prevalence of diabetes for 2011 and 2030. Diabetes Res Clin Pract 2011; 94: 311-321 [PMID: 22079683]

46. Jiang YD, Chang CH, Tai TY, Chen JF, Chuang LM. Incidence and prevalence rates of diabetes mellitus in Taiwan: analysis of the 2000-2009 Nationwide Health Insurance database. J Formos Med Assoc 2012; 111: 599-604 [PMID: 23217595]

47. Guariguata L, Whiting DR, Hambleton I, Beagley J, Linnenkamp U, Shaw JE. Global estimates of diabetes prevalence for 2013 and projections for 2035. Diabetes Res Clin Pract 2014; 103: 137-149 [PMID: 24630390]

48. Satman I, Yilmaz T, Sengül A, Salman S, Salman F, Uygur S, Karsidag K, Kalaca S, Ozcan C, King H. .Population-based study of diabetes and risk characteristics in Turkey: results of the turkish diabetes epidemiology study (TURDEP). Diabetes care 2002; 25: 1551-1556 [PMID: 12196426]

49. Imkampe AK, Gulliford MC. Increasing socio-economic inequality in type 2 diabetes prevalence-repeated cross-sectional surveys in England 1994-2006. Eur J Public Health 2010; 21 : 484-490 [PMID: 20685812]

50. Panagiotakos DB, Pitsavos C, Chrysohoou C, Stefanadis C. The epidemiology of Type 2 diabetes mellitus in Greek adults: the ATTICA study. Diabetic Med 2005; 22: 1581-1588 [PMID: 16241925]

51. International Diabetes Federation. IDF Diabetes atlas. 7th Edition. 2015. International Diabetes Federation, Brussels. http://www.idf.org/diabetesatlas/ (accessed Nov 6, 2015).

52. Frese T, Sandholzer H, Voigt S, Voigt R. Epidemiology of Diabetes Mellitus in German General Practitioners' Consultation-Results of the SESAM 2-study. Exp Clin Endocrinol Diabetes 2008; 116: 326-328 [PMID: 18700277]

53. Go MF. Review article: natural history and epidemiology of Helicobacter pylori Aliment Pharmacol Ther 2002;16 Suppl 1: 3-15 [PMID: 11849122 DOI: 10.1046/j.1365-2036.2002.0160s1003.x]

54. Marshall BJ, Warren JR. Unidentified curved bacilli in the stomach of patients with gastritis and peptic ulceration. Lancet 1984; 1: 1311-1315 [PMID:6145023 ]

55. Hooi JK, Lai WY, Ng WK, Suen MM, Underwood FE, Tanyingoh D, Wu JCY, Chan FKL, Sung JJY, Kaplan GG, Ng SC. Global prevalence of Helicobacter pylori infection: systematic review and meta-analysis. Gastroenterology 2017; 153: 420-429 [PMID: 28456631]

56. Lee YC, Chiang TH, Chou CK, Tu YK, Liao WC, Wu MS, Graham DY. Association between Helicobacter pylori eradication and gastric cancer incidence: a systematic review and meta-analysis. Gastroenterology 2016; 150: 1113-1124. e5 [PMID: 26836587 DOI: 10.1053/j.gastro.2016.01.028]

57. Bravo D, Hoare A, Soto C, Valenzuela MA, Quest AF. Helicobacter pylori in human health and disease: Mechanisms for local gastric and systemic effects. World J Gastroenterol 2018; 24:3071-3089 [ PMID: 30065554]

58. Ražuka-Ebela D, Giupponi B, Franceschi F. Helicobacter pylori and extragastric diseases. Helicobacter 2018; Supp 1 [DOI: 10.1111/hel.12520]

59. NCD Risk Factor Collaboration. Worldwide trends in diabetes since 1980: a pooled analysis of 751 population-based studies with 4 . 4 million participants. The Lancet 2016; 387: 1513-1530 [DOI: 10.1016/S0140-6736(16)00618-8]

60. Wandell PE, Carlsson AC. Gender differences and time trends in incidence and prevalence of type 2 diabetes in Sweden-a model explaining the diabetes epidemic worldwide today? Diabetes Res Clin Pract 2014; 106: e90-92 [PMID: 25451899]

61. American Diabetes Association. Diagnosis and classification of diabetes mellitus. Diabetes Care 2012; 35 Suppl 1: 64-71 [PMID: ]

62. Yuhara H, Steinmaus C, Cohen SE, Corley DA, Tei Y, Buffler PA. Is diabetes mellitus an independent risk factor for colon cancer and rectal cancer? Am J Gastroenterol 2011; 106: 1911-1921 [PMID: 21912438]

63. Koster I, Schubert I, Huppertz E. Follow up of the CoDiM-Study: cost of diabetes mellitus 2000-2009. Dtsch Med Wochenschr2012; 137:1013-1016 [PMID: 22549261]

64. Schunk M, Reitmeir P, Schipf S, Muller G, Ellert U,Neuhauser H, Tamayo T, Rathmann W, Holle R. Health-related quality of life in subjects with and without Type 2 diabetes: pooled analysis of five population-based surveys in Germany. Diabet Med 2012; 29:646653 [PMID: 21978176] 
65. Hwang CK, Han PV, Zabetian A, Ali MK, Narayan KM. Rural diabetes prevalence quintuples over twenty-five years in low- and middleincome countries: a systematic review and meta-analysis. Diabetes Res Clin Pract 2012; 96: 271-85 [PMID: 22261096]

66. Zuo H, Shi Z, Hussain A. Prevalence, trends and risk factors for the diabetes epidemic in China: a systematic review and metaanalysis. Diabetes Res Clin Pract 2014; 104: 63-72 [PMID: 24468097 DOI: 10.1016/j.diabres.2014.01.002]

67. Jayawardena R, Ranasinghe P, Byrne NM, Soares MJ, Katulanda P, Hills AP. Prevalence and trends of the diabetes epidemic in South Asia: a systematic review and meta-analysis. BMC Public Health 2012; 12: 380 [PMID: 22630043]

68. Satman I, Omer B, Tutuncu Y, Kalaca S, Gedik S, Dinccaq N, Karsidag K, Genc S, Telci A .Twelve-year trends in the prevalence and risk factors of diabetes and prediabetes in Turkish adults. Eur J Epidemiol2013; 28: 169-80 [PMID: 23407904]

69. Alharbi NS, Almutari R, Jones S, Al-Daghri N, Khunti K, de Lusignan S. Trends in the prevalence of type 2 diabetes mellitus and obesity in the Arabian Gulf States: systematic review and meta-analysis. Diabetes Res Clin Pract 2014; 106: e30-33 [PMID: 25241351]

70. Menke A, Casagrande S, Geiss L, Cowie CC. Prevalence of and trends in diabetes among adults in the United States, $1988-2012$. JAMA 2015; 314: 1021-29 [PMID: 26348752]

71. Imkampe AK, Gulliford MC. Increasing socio-economic inequality in type 2 diabetes prevalence-repeated cross-sectional surveys in England 1994-2006. Eur J Public Health 2011; 21: 484-90 [PMID: 20685812 DOI: 10.1093/eurpub/ckq 106]

72. Icks A, Moebus S, Feuersenger A, Haastert B, Jockel KH, Giani G. Diabetes prevalence and association with social status-widening of a social gradient? German national health surveys 1990-1992 and 1998. Diabetes Res Clin Pract 2007; 78: 293-97 [PMID: 17532522]

73. Teuscher AU, Diem P, Thomas W, Janett J, Teuscher A. Incidence of insulin-dependent diabetes mellitus in Switzerland (1972-1993) in 19-year-old men. Schweiz Med Wochenschr1995; 125: 1041-45 [PMID: 7770760]

74. De Kort S, Keszthelyi D, Masclee AAM. Leaky gut and diabetes mellitus: what is the link? Obes Rev 2011; 12: 449-458 [PMID: 21382153]

75. Gallimore AM, Godkin A. Epithelial barriers, microbiota, and colorectal cancer. N Engl J Med 2013; 368: $282-284$ [PMID: 23323906 DOI: 10.1056/NEJMcibr1212341]

\section{Tables}

Table 1 Demographics and outcome characteristics of included Group 1 to group 4 studies 


\begin{tabular}{|c|c|c|c|c|c|c|c|c|c|c|c|c|c|}
\hline t author & $\begin{array}{l}\text { Study } \\
\text { duration }\end{array}$ & $\begin{array}{l}\text { Study } \\
\text { location }\end{array}$ & $\begin{array}{l}\text { Study } \\
\text { design }\end{array}$ & $\begin{array}{l}\text { H. pylori } \\
\text { detection }\end{array}$ & $\begin{array}{l}\text { Sample } \\
\text { size }\end{array}$ & $\begin{array}{l}\text { Mean } \\
\text { age } \\
\text { (years) }\end{array}$ & $\begin{array}{l}\text { Gender } \\
(\% \\
\text { male) }\end{array}$ & $\begin{array}{l}\text { Odds } \\
\text { ratio* }\end{array}$ & $\begin{array}{l}95 \% \\
\mathrm{CI}\end{array}$ & $\begin{array}{c}\text { H. pylori } \\
\text { infection } \\
\text { rate (\%) } \\
\#\end{array}$ & $\begin{array}{c}\text { Estimate } \\
\text { DM } \\
\text { prevalence } \\
(\%)\end{array}$ & $\begin{array}{l}\mathrm{DM} \\
\text { prevalence } \\
\text { Reference }\end{array}$ & Reference \\
\hline \multicolumn{14}{|c|}{ up 1 (DM prevalence < } \\
\hline lheshwar & $\begin{array}{l}1997- \\
1999\end{array}$ & UK & $\begin{array}{l}\text { Cross- } \\
\text { section }\end{array}$ & Serology & 236 & 62.21 & 44.92 & 1.08 & $\begin{array}{l}0.58 \\
- \\
1.99\end{array}$ & 35.5 & 4.3 & 49 & 27 \\
\hline . JM & 2005 & Taiwan & $\begin{array}{l}\text { Cross- } \\
\text { section }\end{array}$ & UBT(C13) & 462 & 49.97 & 57.79 & 1.06 & $\begin{array}{l}0.69- \\
1.62\end{array}$ & 53.9 & 5.56 & 46 & 6 \\
\hline o AG & $\begin{array}{l}2005- \\
2007\end{array}$ & Brazil & $\begin{array}{l}\text { Case- } \\
\text { control }\end{array}$ & Serology & 188 & 59.79 & 46.88 & 1.98 & $\begin{array}{l}0.82 \\
- \\
3.15\end{array}$ & 71.2 & 5.8 & 45 & 34 \\
\hline \multicolumn{14}{|c|}{ Iup 2 (DM prevalence: 6 ～ 8 \%) } \\
\hline $\mathrm{YL}$ & $\begin{array}{l}2004- \\
2006\end{array}$ & Taiwan & $\begin{array}{l}\text { Cross- } \\
\text { section }\end{array}$ & CLO test & 9311 & 52.84 & 41.95 & 1.366 & $\begin{array}{l}1.23- \\
1.517\end{array}$ & 53.9 & 6.94 & 24 & 24 \\
\hline rgopoulos & $\begin{array}{l}2000- \\
2001\end{array}$ & Greece & $\begin{array}{l}\text { Case- } \\
\text { control }\end{array}$ & Serology & 156 & 64.25 & NA & 1.83 & $\begin{array}{l}0.88 \\
- \\
3.78\end{array}$ & 52.1 & 7 & 51 & 33 \\
\hline mori $\mathrm{S}$ & $\begin{array}{l}1996- \\
2003\end{array}$ & Japan & $\begin{array}{l}\text { Cross- } \\
\text { section }\end{array}$ & $\begin{array}{l}\text { UBT and } \\
\text { CLO }\end{array}$ & 669 & 61.08 & 70.25 & 1.6 & $\begin{array}{l}1.18 \\
- \\
2.12\end{array}$ & 51.7 & 7.07 & 50 & 28 \\
\hline te & $\begin{array}{l}1996- \\
2004\end{array}$ & Japan & $\begin{array}{l}\text { Case- } \\
\text { control }\end{array}$ & Serology & 478 & 49.7 & 100 & 2.26 & $\begin{array}{l}1.44 \\
- \\
3.55\end{array}$ & 51.7 & 7.07 & 50 & 9 \\
\hline tuely, H & $\begin{array}{l}2008- \\
2010\end{array}$ & Israel & $\begin{array}{l}\text { Cross- } \\
\text { section }\end{array}$ & Serology & 273 & 64.5 & NA & 4.07 & $\begin{array}{l}2.26 \\
- \\
7.35\end{array}$ & 68.9 & 7.1 & 47 & 31 \\
\hline in $A$ & $\begin{array}{l}1996- \\
1997\end{array}$ & Turkey & $\begin{array}{l}\text { Cross- } \\
\text { section }\end{array}$ & Serology & 267 & 49.13 & 45.32 & 2.63 & $\begin{array}{l}1.26 \\
- \\
5.48\end{array}$ & 77.2 & 7.2 & 48 & 26 \\
\hline $\begin{array}{l}\text { ler- } \\
\text {;chinski }\end{array}$ & $\begin{array}{l}1993- \\
1996\end{array}$ & Germany & $\begin{array}{l}\text { Case- } \\
\text { control }\end{array}$ & Serology & 196 & 62.4 & NA & 2.1 & $\begin{array}{l}1.1- \\
3.9\end{array}$ & 35.3 & 7.2 & 53 & 32 \\
\hline uno & 2005 & $\begin{array}{l}\text { Japan } \\
\text { nce: } 8 \text { }\end{array}$ & $\begin{array}{l}\text { Cross- } \\
\text { section } \\
10 \%)\end{array}$ & Serology & 305 & 59.8 & 57.33 & 3.4 & $\begin{array}{l}1.9- \\
6.08\end{array}$ & 51.7 & 7.45 & 43 & 21 \\
\hline gtawee $\mathrm{T}$ & $2014-$ & Thailand & $\begin{array}{l}\text { Cross- } \\
\text { section }\end{array}$ & Pathology & 303 & NA & 38.28 & 7.29 & $\begin{array}{l}2.74- \\
19.36\end{array}$ & 43.6 & 8 & 52 & 40 \\
\hline $\mathrm{RC}$ & $\begin{array}{l}2005- \\
2008\end{array}$ & Korea & $\begin{array}{l}\text { Case- } \\
\text { control }\end{array}$ & $\begin{array}{l}\text { UBT and } \\
\text { CLO }\end{array}$ & 346 & 54.1 & 74.57 & 1.037 & $\begin{array}{l}0.67 \\
- \\
1.59\end{array}$ & 54.0 & 8.6 & 45 & 29 \\
\hline TJ & $\begin{array}{l}2002- \\
2010\end{array}$ & Korea & $\begin{array}{l}\text { Cross- } \\
\text { section }\end{array}$ & Serology & 8916 & 51.6 & 100.00 & 1.37 & $\begin{array}{l}1.18 \\
- \\
1.58\end{array}$ & 54.0 & 8.6 & 45 & 35 \\
\hline $1 \mathrm{JH}$ & $\begin{array}{l}2007- \\
2009\end{array}$ & Korea & $\begin{array}{l}\text { Case- } \\
\text { control }\end{array}$ & CLO & 4466 & NA & 53.63 & 1.28 & $\begin{array}{l}1.11 \\
-1.47\end{array}$ & 54.0 & 8.6 & 45 & 36 \\
\hline JY & $\begin{array}{l}2012- \\
2013\end{array}$ & Korea & $\begin{array}{l}\text { Cross- } \\
\text { section }\end{array}$ & Serology & 6351 & 51.7 & 52.79 & 1.28 & $\begin{array}{l}1.09- \\
1.36\end{array}$ & 54.0 & 8.9 & 45 & 39 \\
\hline g SN & 2010 & Korea & $\begin{array}{l}\text { Cross- } \\
\text { section }\end{array}$ & Serology & 2195 & 49.23 & 62.00 & 1.36 & $\begin{array}{l}1.1- \\
1.68\end{array}$ & 54.0 & 9 & 47 & 25 \\
\hline ᄃ YM & $\begin{array}{l}2008- \\
2012\end{array}$ & Korea & $\begin{array}{l}\text { Cross- } \\
\text { section }\end{array}$ & Serology & 2781 & 44.8 & 58.72 & 2.26 & $\begin{array}{l}1.11- \\
4.62\end{array}$ & 54.0 & 9.0 & 47 & 38 \\
\hline 1 KW & $\begin{array}{l}2004- \\
2005\end{array}$ & Korea & $\begin{array}{l}\text { Cross- } \\
\text { section }\end{array}$ & Serology & 598 & 56.23 & 65.38 & 1.93 & $\begin{array}{l}1.24- \\
3.01\end{array}$ & 54.0 & 8.8 & 45 & 8 \\
\hline KC & $\begin{array}{l}2006- \\
2015\end{array}$ & Taiwan & $\begin{array}{l}\text { Cross- } \\
\text { section }\end{array}$ & CLO & 2475 & 52.90 & 66.91 & 1.44 & $\begin{array}{l}1.20 \\
-1.73\end{array}$ & 53.9 & 9.59 & 19 & 19 \\
\hline \multicolumn{14}{|c|}{$\operatorname{lup}_{\%)} 4$ (DM prevalence: > } \\
\hline Ye & $\begin{array}{l}2014- \\
2016\end{array}$ & China & $\begin{array}{l}\text { Cross- } \\
\text { section }\end{array}$ & UBT & 1641 & 50.73 & 66.24 & 1.535 & $\begin{array}{l}1.04 \\
-1.75\end{array}$ & 55.8 & 10.6 & 52 & 37 \\
\hline a H & $\begin{array}{l}2005- \\
2009\end{array}$ & USA & $\begin{array}{l}\text { Cross- } \\
\text { section }\end{array}$ & pathology & 1256 & 57 & 34.00 & 1.5 & $\begin{array}{l}1.2- \\
2.2\end{array}$ & 35.6 & 10.7 & 44 & 22 \\
\hline $\operatorname{rad} \mathbf{M}$ & $\begin{array}{l}2008- \\
2013\end{array}$ & Germany & $\begin{array}{l}\text { Cross- } \\
\text { section }\end{array}$ & Serology & 377 & 66.38 & 50.13 & 1.85 & $\begin{array}{l}1.14- \\
2.99\end{array}$ & 35.3 & 11.9 & 47 & 23 \\
\hline nenberg & $\begin{array}{l}2008- \\
2011\end{array}$ & USA & $\begin{array}{l}\text { Cross- } \\
\text { section }\end{array}$ & pathology & 22231 & 57.8 & 41.00 & 1.52 & $\begin{array}{l}1.46 \\
-1.57\end{array}$ & 35.6 & 12.1 & 44 & 3 \\
\hline ass $K$ & $\begin{array}{l}2008- \\
2009\end{array}$ & USA & $\begin{array}{l}\text { Cross- } \\
\text { section }\end{array}$ & CLO & 192 & 59.1 & 38.02 & 1.29 & $\begin{array}{l}0.69 \\
-\end{array}$ & 35.6 & 12.1 & 44 & 30 \\
\hline $1 \mathrm{~S}$ & $\begin{array}{l}2009- \\
2011\end{array}$ & USA & $\begin{array}{l}\text { Case- } \\
\text { control }\end{array}$ & Pathology & 798 & 54.82 & NA & 1.04 & $\begin{array}{l}2.42 \\
0.67- \\
1.61\end{array}$ & 35.6 & 12.1 & 44 & 42 \\
\hline iga $\mathbf{R}$ & $\begin{array}{l}2010- \\
2012\end{array}$ & USA & $\begin{array}{l}\text { Case- } \\
\text { control }\end{array}$ & NA & 943 & 57 & NA & 1.55 & $\begin{array}{l}1.13- \\
2.12\end{array}$ & 35.6 & 12.3 & 44 & 41 \\
\hline
\end{tabular}

ds ratio: for colorectal adenoma; * from reference 57; Siddheshwar RK study only included colon polyp population; Nam JH, Tongtawee T studies only onstrated aging disturbance;

s YM focus age 40-49 subjects; Sonnenberg only included subjects who had $H$. pylori pathology report 


\section{Figures}

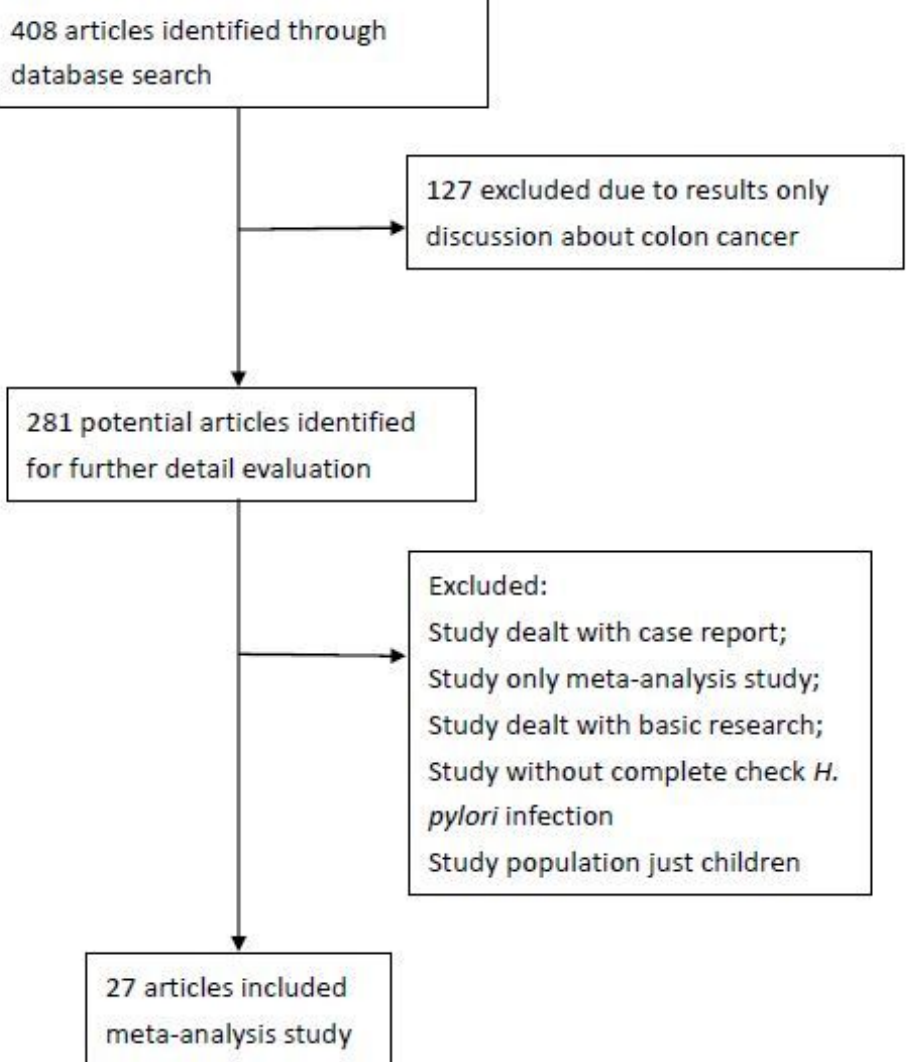

\section{Figure 1}

Flow diagram of the studies identified in this meta-analysis 


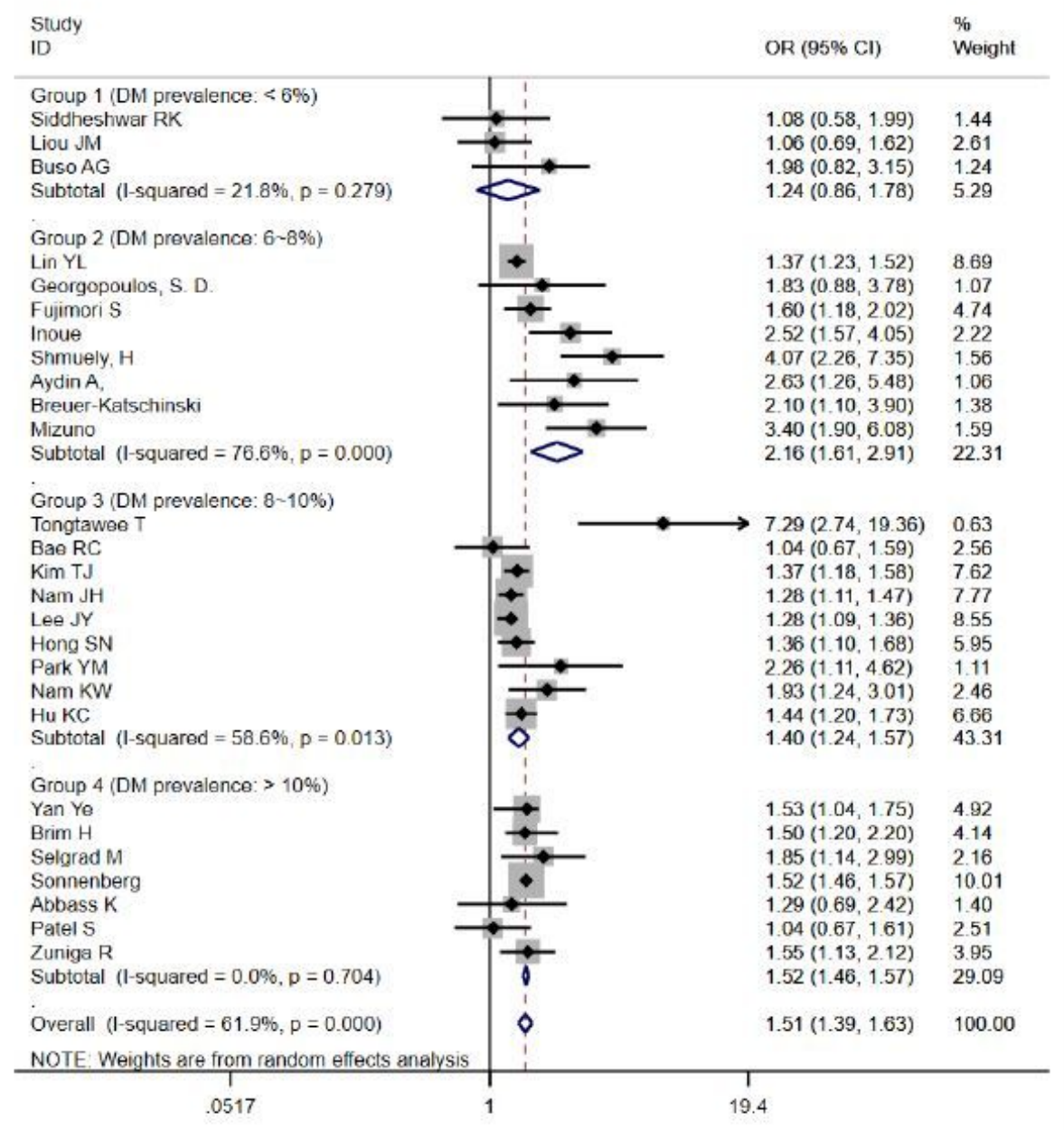

\section{Figure 2}

Forest plot showing individual and pooled odds ratio [95\% confidence intervals (Cls)] of all studies included with subgroups of the prevalence of DM. Each study is labeled with the authors' name.
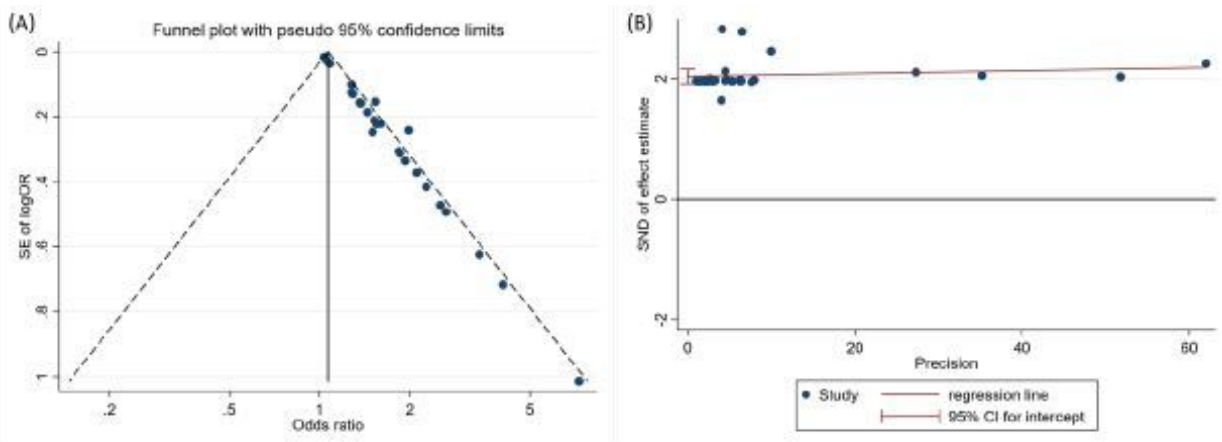

\section{Figure 3}

(A) Funnel plot of all studies included examining the relation between Helicobacter pylori infection and colon adenoma. (B) Egger's regression test of all studies including the relation between Helicobacter pylori infection and colon adenoma.

\section{Supplementary Files}

This is a list of supplementary files associated with this preprint. Click to download. 
- supplement1.docx

- supplement2.pdf

Page 14/14 